\title{
Identifying Factors behind the Decline in the U.S. Labor Force Participation Rate
}

\author{
Julie L. Hotchkiss (Corresponding author) \\ Federal Reserve Bank of Atlanta and Georgia State University \\ Research Department, 1000 Peachtree St NE, Atlanta, GA, USA 30309-4470 \\ E-mail: Julie.L.Hotchkiss@atl.frb.org
}

Fernando Rios-Avila

Georgia StateUniversity, Atlanta, GA, USA

E-mail: friosavila1@gsu.edu

Received: March 12, 2013 Accepted: March 29, 2013

doi:10.5296/ber.v3i1.3370

URL: http://dx.doi.org/10.5296/ber.v3i1.3370

\begin{abstract}
The analysis in this paper finds that the dramatic decline in labor force participation during the Great Recession is more than explained by deteriorating labor market conditions (cyclical factors). Behavior adjusted over this time period to boost labor force participation so that it was higher in 2012 than would have been predicted by the model. Depending on the strength of the labor market going forward, we project anywhere from a further decline in the labor force participation rate of $0.8 \mathrm{pp}$ to an increase of $0.35 \mathrm{pp}$ by 2017.
\end{abstract}

Keywords: Labor force participation, Oaxaca decomposition, Great Recession

\section{Introduction and Background}

Since the early 1960s, a steady upward trend of the labor force participation rate (LFPR) was observed in the U.S. labor market (see Figure 1). Most of this increase has been explained by the rise of women in the labor market, the progression of baby boomers into their primary working years, and the later retirement ages of workers. This rising LFPR stalled by the end of the 1990s, and has been on a relatively dramatic decline ever since (with a bit of a hiatus in the mid-2000s). The most dramatic decline began during the 2008-2009 recession -- LFPR declined from $66 \%$ in 2007 to $63.7 \%$ in 2012. 


\section{MInstitute Macrothink $^{\mathrm{m}}$}

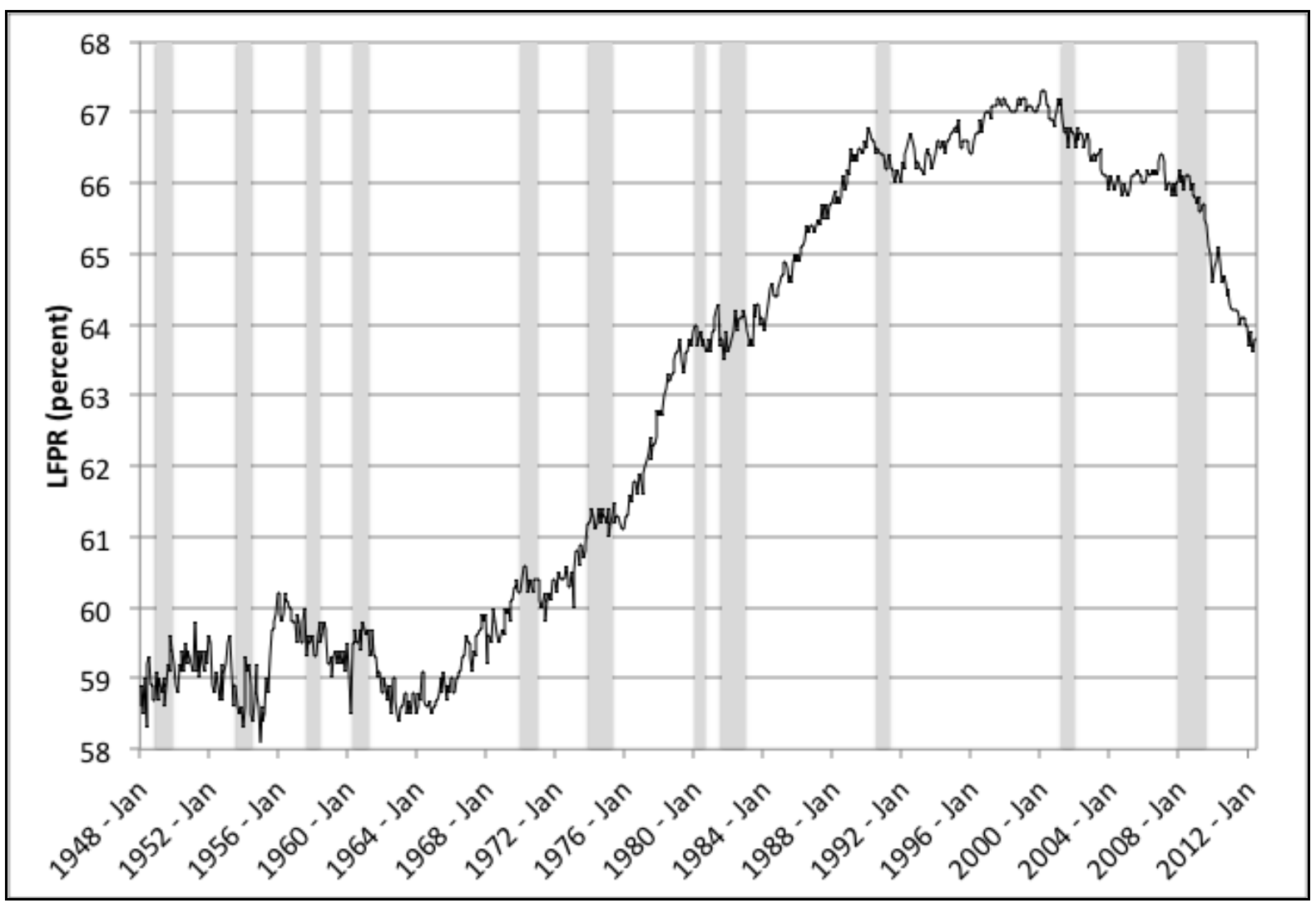

Figure 1. Labor Force Participation Rate, January 1948 - June 2012.

Figure 1 motivates two questions, (1) what has caused the dramatic decline in the LFPR, and (2) can it be expected to continue? Answering the first question (the source) could provide some insight to answering the second question (momentum). Interest in movements in labor force participation derives primarily from an interest in fueling potential economic growth (i.e., constrained participation restricts production potential), and from the importance that even short-term fluctuations in labor force participation have been found to have in the determination of observed unemployment rates (see Kudlyak and Schwartzman 2012 and Elsby et al. 2012).

This paper decomposes the change in the LFPR that occurred from pre- to post- 2008-2009 recession. The methodology identifies what portion of that decline can be attributable to changes in demographics, changes in behavior, and changes in labor market conditions. We find that over this time period, deteriorating labor market conditions explain more than the entire drop in observed LFPR and that behavior changed in the opposite direction, preventing an even greater decline of the LFPR. The implication is that even if workers return to pre-recessionary behavior, continued improvement in the labor market will have a significant positive influence on participation decisions, partially offsetting the ongoing demographic changes.

Other analyses of movements in the LFPR across the Great Recession attribute anywhere from one-half to three-quarters of the decline to deterioration in the labor market (e.g., Maki 2012, Aaronson et al. 2012; Van Zandweghe 2012, and Stehn 2012).By accounting for changes in individual behavior and by allowing behavior to be directly related to changes in the business 
cycle, we find changes in labor market conditions accounted for more than 100 percent of the observed decline in labor force participation.

\section{Empirical Strategy}

The empirical strategy adopted here to identify the factors behind the observed decline in the LFPR is to decompose the change from before to after the 2007-2008 recession into observed changes in socio-demographics and the labor market and estimated changes in behavior. Ideally, an estimate of the impact of an event, such as a recession, on an observed outcome, such as labor force participation, would involve comparing the behavior of people after the event to what their behavior would have been if the event had not occurred. Since this is not possible, the typical alternative is to compare the outcome between two samples -- one observed before the event and one observed after the event, comparing changes in the characteristics of the two samples and changes in how those characteristics produced the outcome (behavior); for example, see Hotchkiss 2005. In other words, typical analyses would apply the standard Oaxaca-Blinder decomposition (see Blinder 1973 and Oaxaca 1973).

As pointed out in Barsky et al. (2002), however, the standard Oaxaca-Blinder strategy may not provide consistent estimates of the decomposition if the relationship of interest is nonlinear. In such a case, the conditional expectation of the outcome for one sample (e.g., post-recession) is not an accurate representation for the conditional expectation of the outcome for the other sample (e.g., pre-recession). Barsky et al. also point out that unless one knows the exact form of the nonlinearity, just adding quadratic terms does not solve the problem.

Furthermore, if one is trying to evaluate the impact of an event on an outcome, the comparison will be biased if the control and treatment groups are structurally different, particularly if the differences arise because of the event. For example, in this particular case, an economic recession is theorized to directly reduce the incentive to participate in the labor market (i.e., with lower employment opportunities the expected wage may fall below a person's reservation wage, reducing the likelihood of participating in the labor force). In addition, however, with fewer employment opportunities, the opportunity cost of other activities, such as attending school, also falls, which may result in an observed increase in educational attainment post-recession (as documented by Hotchkiss et al. 2012). There is also evidence that the Great Recession reduced fertility and may have affected marriage and cohabitation rates (Morgan et al. 2012) -- number of children and marriage are characteristics strongly related to labor force participation decisions. The result is that any of the change in the observed LFPR attributed to changes in characteristics may be confounding influences of the weaker labor market on behavior.

In order to address these sources of potential bias and disentangle labor market condition factors from behavioral factors (as observed through changes in characteristics), we decompose the observed differences in the LFPR from before to after the recession by first creating a counterfactual distribution using a re-weighting strategy similar to DiNardo et al. (1996) and described in Fortin et al. (2010). The strategy is to construct a counterfactual distribution for observed labor force participation after the recession such that observed characteristics (i.e. socio-demographic characteristics) resemble the distribution of 
observations prior to the recession. This counterfactual distribution serves as the next best alternative to being able to observe individuals as if the recession had not affected their endowments. Operationally, the counterfactual distribution is obtained by weighting post-recession observations with the inverse probability of being observed post-recession. This procedure is analogous to that advocated by Hirano et al. (2003) to obtain treatment effects.

Weights are constructed by thinking of time (pre- and post- recession) as a state variable (or, as a treatment variable) and estimating a logit model where the dependent variable is a dummy that indicates the post-recession status $(T=1)$ of individual $i$, using observations of individuals from both time periods:

$$
P_{\mathrm{i}}\left(T=1 \mid X_{\mathrm{i}}\right)=\Lambda\left(X_{\mathrm{i}}^{v} \lambda\right)
$$

$X_{\tilde{I}}$ corresponds to the socio-demographic characteristics observed for person $i$, including sex, age, education level, marital status, number of children, ethnicity, and non-labor income. In addition, given the main interest of the paper, a measure of individual labor market conditions is also included. Following the suggestions of Firpo et al. (2007), the logit model includes various interactions between age, education, ethnicity, and labor market conditions to improve the fitness of the model and to allow for non-linear relationships. Parameter estimates from equation (1) are then used to construct the weights that will be applied in the estimation using the post-recession sample in order to construct the post-recession counterfactual distribution: ${ }^{\text {ii }}$

$$
\omega_{\mathrm{i}}\left(X_{\mathrm{i}}\right)=\frac{1-\Lambda\left(X_{\mathrm{i}}^{\prime} \mathrm{R}\right)}{\Lambda\left(X_{\mathrm{i}}^{\prime} \tilde{\lambda}\right)}
$$

Under the assumptions of ignorability (conditional on measured covariates) and overlapping support of the covariates (see Imbens and Wooldridge 2009 for details), the counterfactual distribution of the pre-recession sample can be identified and used to the disentangled contributions of behavioral changes and changes in sample characteristics on the labor force participation decisions. ${ }^{\text {iii }}$

\subsection{Decomposition Details}

Three linear probability models associating the probability of individual $i$ being in the labor force in year $t\left(L F P_{i t}=1\right)$, given his/her age, sex, race, education, marital status, number of children, and non-labor income $\left(X_{\text {it }}\right)$; and labor market conditions $\left(L M_{i t}\right)$ are estimated: ${ }^{\text {iv }}$

$$
\begin{aligned}
& L F P_{i t}=\alpha_{0}+X_{i t}^{v} \beta_{0}+\gamma_{0} L M_{i t}+\varepsilon_{0, i t} \text { for } \mathrm{t}=\{2005,2006,2007\} \\
& L F P_{i t}=\alpha_{1}+X_{i t}^{v} \beta_{1}+\gamma_{1} L M_{i t}+\varepsilon_{1, i t} \text { for } \mathrm{t}=\{2010,2011,2012\} \\
& \widetilde{L F P} P_{i t}=\widetilde{\alpha}_{1}+\widetilde{X}_{i t}^{s} \widetilde{\beta}_{1}+\widetilde{\gamma}_{1} \widetilde{L M}_{i t}+\eta_{i t} \text { for } \mathrm{t}=\{2010,2011,2012\}
\end{aligned}
$$

Equations (3) and (4) are the typical pre- and post-recession estimation that would be used in order to perform the standard Oaxaca-Blinder decomposition. Equation (5) is estimated using the weights constructed in equation (2).

Using the parameter coefficients from estimating equations (3)-(5), the observed difference in the average pre- and post-recession LFPRs is decomposed into its different contributing factors in the following way (recall, the counterfactual distribution is constructed so that $\overline{\tilde{X}}_{1} \simeq \bar{X}_{0}$ and 


\section{1l Macrothink}

Business and Economic Research

$\left.\widehat{\hat{\beta}}_{1} \simeq \hat{\beta}_{1}\right):$

$$
\begin{aligned}
& \overline{L F P}_{1}-\overline{L F P}_{0}=\quad \leftarrow \text { total change in LFPR } \\
& \left(\hat{\alpha}_{1}-\hat{\alpha}_{0}\right) \quad \leftarrow \text { contribution unexplained from other factors } \\
& +\left[\bar{X}_{1}^{s} \hat{\beta}_{1}-\overline{\tilde{X}}_{1}^{s} \hat{\beta}_{1}\right] \leftarrow \text { contribution from change in characteristics } \\
& +\left[\overline{\tilde{X}}_{1}^{r} \hat{\tilde{\beta}}_{1}-\bar{X}_{0}^{s} \hat{\beta}_{0}\right] \leftarrow \text { contribution from change in behavior } \\
& +\left[\widehat{\gamma}_{1} \widetilde{L M}_{1}-\widehat{\hat{\gamma}}_{1} \overline{L M}_{1}\right] \leftarrow \text { contribution from change in LM conditions } \\
& +\left[\widehat{\hat{\gamma}}_{1} \widetilde{L M}_{1}-\hat{\gamma}_{0} \widetilde{L M}_{0}\right] \leftarrow \text { contribution from responses to LM conditions }
\end{aligned}
$$

In addition to the decomposition strategy described here, we also perform a standard Oaxaca-Blinder decomposition and report these results in Appendix 2. While the decomposition differs between the two strategies in expected ways (to be discussed below), both strategies lead to the same conclusions about the relative contributions of changes in socio-demographic characteristics, behavior, and the labor market.

A question arises as to how one measures the condition of the labor market. Others have made use of lagged unemployment rates (e.g., see Van Zandweghe 2012 and Hotchkiss 2005) and even more aggregated measures of the business cycle, such as the GDP gap (e.g., Aaronson et al. 2012). We argue that state and year specific average weeks worked in the previous year more closely aligns conditions of the labor market with individual labor supply decisions. The LFPR is a construct based on decisions made by the entire population (16 years and older), whereas movements of the unemployment rate only capture business cycle fluctuations affecting those who have already decided to be in the labor force. Average weeks worked reflects labor market fluctuations affecting the entire population. In addition, a falling unemployment rate could result from two very different labor market conditions. On the one hand, people moving from unemployment to employment lowers the unemployment rate in the way we think of most often. But the unemployment rate will also fall (albeit, by a lesser amount) if the same number of unemployed leave the labor force, rather than find employment. In the first case, average weeks worked increases (a positive sign), whereas in the second case, average weeks worked is unchanged (no improvement). Consequently, we make use of the aggregated, state- and year-specific average of weeks worked in the previous year. This aggregated measure is no more endogenous to an individual's labor supply decision than the commonly used aggregate unemployment rate. In addition, we also estimate the model using the lagged aggregate unemployment rate instead with no appreciable difference in results.

\subsection{The Data}

The data set used for the analysis consists of individual observations from the March Current Population Survey (CPS). The CPS is a monthly survey administered by the Bureau of Labor Statistics in order to assess the activities of the population, estimate the number of people who 
are employed and unemployed, and subsequently estimate the number of people in the labor force, the labor force participation rate, and the unemployment rate. We make use of the March Supplement of the CPS because it contains information about the previous year's labor market activity and a measure of non-labor income. Observations from 2005 through 2007 are combined to produce the pre-recession sample and observations from 2010-2012 make up the post-recession sample.

\section{Results}

The first order of business in the implementation of the estimation strategy described above is to construct a counterfactual distribution for labor force participation for the post-recession sample. Table 1 contains the results from the reweighting exercise that produces the counterfactual distribution. Statistical t-tests confirm that most of the means of the two samples pre- and post-recession are statistically significantly different from one another, and that the reweighting procedure is successful in producing a counterfactual post-recession distribution that is statistically identical to the pre-recession sample at the mean ( $\mathrm{t}$-stat values, for the most part, are all less than one).

Table 1. Results from reweighting post-recession sample

\begin{tabular}{|c|c|c|c|c|c|c|c|}
\hline & \multicolumn{3}{|c|}{ Sample Means } & \multicolumn{4}{|c|}{ Comparison of Sample Means } \\
\hline & \multirow{2}{*}{$\begin{array}{c}\text { Pre } \\
\text { Recession }\end{array}$} & \multirow[t]{2}{*}{$\begin{array}{c}\text { Post } \\
\text { Recession }\end{array}$} & \multirow{2}{*}{$\begin{array}{c}\text { Post } \\
\text { Recession } \\
\text { Reweighted }\end{array}$} & \multicolumn{2}{|c|}{$\begin{array}{c}\text { Pre- vs } \\
\text { Post-Recession }\end{array}$} & \multicolumn{2}{|c|}{$\begin{array}{c}\text { Pre-Recession vs } \\
\text { Reweighted } \\
\text { Post-recession }\end{array}$} \\
\hline & & & & t-stat & p-val & t-stat & $\mathrm{p}$-val \\
\hline Age group 16-19 & $\begin{array}{c}0.0728 \\
{[0.0004]}\end{array}$ & $\begin{array}{c}0.0708 \\
{[0.0004]}\end{array}$ & $\begin{array}{c}0.0723 \\
{[0.0004]}\end{array}$ & 3.5172 & 0.0004 & 0.9432 & 0.3456 \\
\hline Age group 20-34 & $\begin{array}{c}0.2610 \\
{[0.0008]}\end{array}$ & $\begin{array}{c}0.2598 \\
{[0.0008]}\end{array}$ & $\begin{array}{c}0.2601 \\
{[0.0008]}\end{array}$ & 1.0936 & 0.2741 & 0.8846 & 0.3764 \\
\hline Age group 35-54 & $\begin{array}{c}0.3747 \\
{[0.0008]}\end{array}$ & $\begin{array}{c}0.3499 \\
{[0.0008]}\end{array}$ & $\begin{array}{c}0.3746 \\
{[0.0008]}\end{array}$ & 21.1951 & 0.0000 & 0.0633 & 0.9495 \\
\hline Age group 55-74 & $\begin{array}{c}0.2172 \\
{[0.0007]}\end{array}$ & $\begin{array}{c}0.2450 \\
{[0.0008]}\end{array}$ & $\begin{array}{c}0.2185 \\
{[0.0007]}\end{array}$ & 25.9843 & 0.0000 & 1.2299 & 0.2187 \\
\hline Female $(=1)$ & $\begin{array}{c}0.5168 \\
{[0.0009]}\end{array}$ & $\begin{array}{c}0.5161 \\
{[0.0009]}\end{array}$ & $\begin{array}{c}0.5177 \\
{[0.0009]}\end{array}$ & 0.5822 & 0.5604 & 0.6967 & 0.4860 \\
\hline \# children younger than 6 & $\begin{array}{c}0.1901 \\
{[0.0008]}\end{array}$ & $\begin{array}{c}0.1745 \\
{[0.0008]}\end{array}$ & $\begin{array}{c}0.1902 \\
{[0.0009]}\end{array}$ & 13.6978 & 0.0000 & 0.0763 & 0.9392 \\
\hline \# children aged 6-18 & $\begin{array}{c}0.4774 \\
{[0.0014]}\end{array}$ & $\begin{array}{c}0.4434 \\
{[0.0013]}\end{array}$ & $\begin{array}{c}0.4764 \\
{[0.0014]}\end{array}$ & 17.4786 & 0.0000 & 0.4802 & 0.6311 \\
\hline Married, Spouse present & $\begin{array}{c}0.5219 \\
{[0.0009]}\end{array}$ & $\begin{array}{c}0.5022 \\
{[0.0009]}\end{array}$ & $\begin{array}{c}0.5225 \\
{[0.0009]}\end{array}$ & 15.9554 & 0.0000 & 0.4746 & 0.6351 \\
\hline High School & $\begin{array}{c}0.3832 \\
{[0.0009]}\end{array}$ & $\begin{array}{c}0.3800 \\
{[0.0008]}\end{array}$ & $\begin{array}{c}0.3828 \\
{[0.0009]}\end{array}$ & 2.6156 & 0.0089 & 0.3265 & 0.7441 \\
\hline Some College & $\begin{array}{c}0.1839 \\
{[0.0007]}\end{array}$ & $\begin{array}{c}0.1875 \\
{[0.0007]}\end{array}$ & $\begin{array}{c}0.1837 \\
{[0.0007]}\end{array}$ & 3.6683 & 0.0002 & 0.2131 & 0.8313 \\
\hline
\end{tabular}




\begin{tabular}{|l|c|c|c|c|c|c|c|}
\hline BA degree & $\begin{array}{c}0.1642 \\
{[0.0007]}\end{array}$ & $\begin{array}{c}0.1754 \\
{[0.0007]}\end{array}$ & $\begin{array}{c}0.1643 \\
{[0.0006]}\end{array}$ & 11.9944 & 0.0000 & 0.2013 & 0.8404 \\
\hline Graduate Degree & $\begin{array}{c}0.0819 \\
{[0.0005]}\end{array}$ & $\begin{array}{c}0.0919 \\
{[0.0005]}\end{array}$ & $\begin{array}{c}0.0821 \\
{[0.0005]}\end{array}$ & 14.3979 & 0.0000 & 0.4236 & 0.6718 \\
& 0.1232 & 0.1282 & 0.1232 & 6.3064 & 0.0000 & 0.0525 & 0.9581 \\
& {$[0.0006]$} & {$[0.0006]$} & {$[0.0006]$} & & & & \\
\hline Hispanic or Black & 45.9927 & 44.7336 & 46.1127 & 8.2239 & 0.0000 & 0.7118 & 0.4766 \\
& {$[0.1092]$} & {$[0.1073]$} & {$[0.1285]$} & & & & \\
\hline Disability Income & 114.3367 & 88.2136 & 119.9517 & 5.8524 & 0.0000 & 0.8098 & 0.4180 \\
& {$[3.4260]$} & {$[2.8613]$} & {$[6.0337]$} & & & & \\
\hline Avg Number of weeks & 31.5132 & 29.4517 & 31.5088 & 596.8887 & 0.0000 & 1.3377 & 0.1810 \\
worked last year & {$[0.0024]$} & {$[0.0025]$} & {$[0.0024]$} & & & & \\
\hline
\end{tabular}

Notes: Standard errors are in parentheses. CPS sample weights are used in the construction of all means.

As was mentioned earlier, we can see the theorized influence of the recession on behavior through fewer children and less marriage, on average, post-recession. We also see the evidence of greater post-recession educational attainment documented in Hotchkiss et al. (2012). Lower non-labor income and fewer average weeks worked in the previous year were also to be expected post-recession. By design, each of these differences at the mean is eliminated through the reweighting procedure.

The results corresponding to the estimation of equations (3)-(5) are found in Appendix 1. All regressors influence labor force participation as expected. Participation increases with age until 55 years; men, those without children, married individuals, the more educated, and those with less non-labor income, ceteris paribus, are more likely to participate in the labor market. And, lastly, stronger labor markets induce greater labor force participation.

Women, individuals with young children, and those who are married with their spouse present are all more likely (holding everything else constant) to be participating post-recession than they were pre-recession. Increased participation among these individuals likely reflects the added worker effect (e.g., see Juhn and Potter 2007). There was no significant difference across the two time periods in how the condition of the labor market affected labor force participation decisions.

\subsection{The Change in LFPR Decomposed}

Table 2 contains the decomposition results described by equation (6). The change in aggregate LFPR from pre- to post-recession was -0.016 (a 1.6 percentage point decline). More than 100 percent of the decline in the LFPR (-0.0350) can be attributed to the decline in labor market conditions. The rest of the endowments changed in such a way as to put upward pressure on labor force participation (+0.0044). Similarly, the coefficients also changed in such a way as to put upward pressure on labor force participation $(+0.0145)$.

Table 2. Detailed decomposition of decline in labor force participation using reweighting strategy and construction of counterfactual post-recession distribution 


\begin{tabular}{|c|c|c|}
\hline$\overline{L F P_{1}}-\overline{L F P_{0}}=0.641-0.657=-0.016$ & $\begin{array}{l}\text { Contribution of } \\
\text { changes in } \\
\text { Endowments }\end{array}$ & $\begin{array}{l}\text { Contribution of } \\
\text { changes in } \\
\text { Coefficients }\end{array}$ \\
\hline Total & $-0.0306 *$ & 0.0143 \\
\hline Age & $-0.0161 *$ & $\begin{array}{l}-0.0027 \\
\end{array}$ \\
\hline Age group 16-19 & $\begin{array}{c}0.0003 \\
{[0.0002]}\end{array}$ & $\begin{array}{l}-0.0067 * \\
{[0.0004]}\end{array}$ \\
\hline Age group 20-34 & $\begin{array}{l}-0.0017+ \\
{[0.0008]}\end{array}$ & $\begin{array}{l}-0.0041 * \\
{[0.0009]}\end{array}$ \\
\hline Age group 35-54 & $\begin{array}{l}-0.0209 * \\
{[0.0009]}\end{array}$ & $\begin{array}{c}0.0000 \\
{[0.0013]}\end{array}$ \\
\hline Age group 55-74 & $\begin{array}{l}0.0063^{*} \\
{[0.0005]}\end{array}$ & $\begin{array}{l}0.0080^{*} \\
{[0.0008]}\end{array}$ \\
\hline Sex and Ethnicity & $-0.0020 *$ & $0.0069^{*}$ \\
\hline Female $(=1)$ & $\begin{array}{l}-0.0005+ \\
{[0.0002]}\end{array}$ & $\begin{array}{l}0.0056^{*} \\
{[0.0010]}\end{array}$ \\
\hline Hispanic or Black & $\begin{array}{l}-0.0015^{*} \\
{[0.0003]}\end{array}$ & $\begin{array}{l}0.0013^{*} \\
{[0.0003]}\end{array}$ \\
\hline Household Characteristics & $0.0016^{*}$ & 0.0012 \\
\hline \# children younger than 6 & $\begin{array}{l}0.0003^{*} \\
{[0.0001]}\end{array}$ & $\begin{array}{l}0.0018^{*} \\
{[0.0004]}\end{array}$ \\
\hline \# children aged 6-18 & $\begin{array}{l}0.0011^{*} \\
{[0.0001]}\end{array}$ & $\begin{array}{l}-0.0023 * \\
{[0.0006]}\end{array}$ \\
\hline Married, Spouse present & $\begin{array}{c}0.0003 \\
{[0.0002]}\end{array}$ & $\begin{array}{c}0.0016 \\
{[0.0012]}\end{array}$ \\
\hline Education & 0.0252* & $-0.0125 *$ \\
\hline High School & $\begin{array}{l}0.0066^{*} \\
{[0.0009]}\end{array}$ & $\begin{array}{l}-0.0042 * \\
{[0.0010]}\end{array}$ \\
\hline Some College & $\begin{array}{l}0.0026^{*} \\
{[0.0005]}\end{array}$ & $\begin{array}{l}-0.0023 * \\
{[0.0005]}\end{array}$ \\
\hline BA degree & $\begin{array}{l}0.0095^{*} \\
{[0.0005]}\end{array}$ & $\begin{array}{l}-0.0035^{*} \\
{[0.0005]}\end{array}$ \\
\hline Graduate Degree & $\begin{array}{l}0.0065^{*} \\
{[0.0004]}\end{array}$ & $\begin{array}{l}-0.0025^{*} \\
{[0.0003]}\end{array}$ \\
\hline Other Income & $-0.0043 *$ & $0.0057^{*}$ \\
\hline Non Labor income & $\begin{array}{l}-0.0044^{*} \\
{[0.0003]}\end{array}$ & $\begin{array}{l}0.0056^{*} \\
{[0.0009]}\end{array}$ \\
\hline
\end{tabular}




\begin{tabular}{|l|c|c|}
\hline \multicolumn{1}{|c|}{ Disability Income } & 0.0001 & 0.0001 \\
& {$[0.0001]$} & {$[0.0001]$} \\
\hline & & \\
\hline Labor Market Conditions & $\mathbf{- 0 . 0 3 5 1 *}$ & $\mathbf{0 . 0 1 5 7}$ \\
& {$[0.0115]$} & {$[0.0162]$} \\
\hline & & \\
\hline Constant & -- & 0.0002 \\
& & {$[0.0114]$} \\
\hline
\end{tabular}

Notes: Robust standard errors in parentheses. Excluded categories include those aged 75+, less than high school education, male, not married, and whites. Urban CPI is used to deflate dollar values of other income. Labor market conditions are measured by the average number of weeks worked in the previous year in by year and state of residence.

$+\mathrm{p}<0.05, * \mathrm{p}<0.01$

Comparing the decomposition results in Table 2 with those in Appendix 2, which contains the standard Oaxaca-Blinder decomposition, illustrates the source of concern about recession-induced characteristic change confounding the amount of change in the LFPR attributed to the change in labor market conditions. The amount of the overall LFPR change attributed to labor market conditions using the Oaxaca-Blinder decomposition is -0.0288 (Table B1), whereas it is -0.0351 using the reweighting methodology (Table 2). These results are consistent with the reweighting procedure removing indirect recessionary influences from sample characteristic changes, leaving more impact to be captured by direct recessionary effects through measured changes in labor market conditions. For example, greater educational attainment and lower fertility post-recession would theoretically result in greater observed labor force participation, which would bias the estimated negative relationship between labor market conditions and labor force participation toward zero. Using the reweighted distribution removes this bias from the decomposition exercise, allowing for a stronger relationship between labor market conditions and participation decisions. However, it is of interest to note that the overall conclusions from the reweighting procedure are the same as from the Oaxaca-Blinder methodology: changing labor market conditions explain more than 100 percent of the change in the LFPR from before to after the recession, and the LFPR would have been even lower if behavior had not changed to prop it up.

\subsection{Trend versus Cycles: Results in Context}

Efforts so far to identify the source for the dramatic decline in the LFPR generally decompose movements in the aggregate LFPR into cyclical and trend components. This is a statistical exercise that isolates the long-term trend (i.e. demographic shifts) from the movements in the aggregated series; the difference between the predicted long-term trend and the actual LFPR is then declared the cyclical contribution to its movements. Estimates of the cyclical component in analyses of the movement in the LFPR from before to after the Great Recession range from one half (Van Zandweghe 2012, comparing 2007 to 2011 changes in the LFPR) to three-quarters (Aaronson et al. 2012, comparing 2008 to 2011 changes in the LFPR). ${ }^{\mathrm{V}}$

Our analysis attributes more than 100 percent of the 1.6pp decline in the LFPR to deterioration 
of the labor market. By allowing for behavioral adjustments across the business cycle, we identify a much stronger role of the current labor market in the determination of an individual's labor force participation decision. The difference in our approach compared to that of other analyses is illustrated in Figure 2, where the typical decomposition between Demographics and the Business Cycle is contrasted with the decomposition provided for through the inclusion of labor market conditions, analogous to our estimations above.

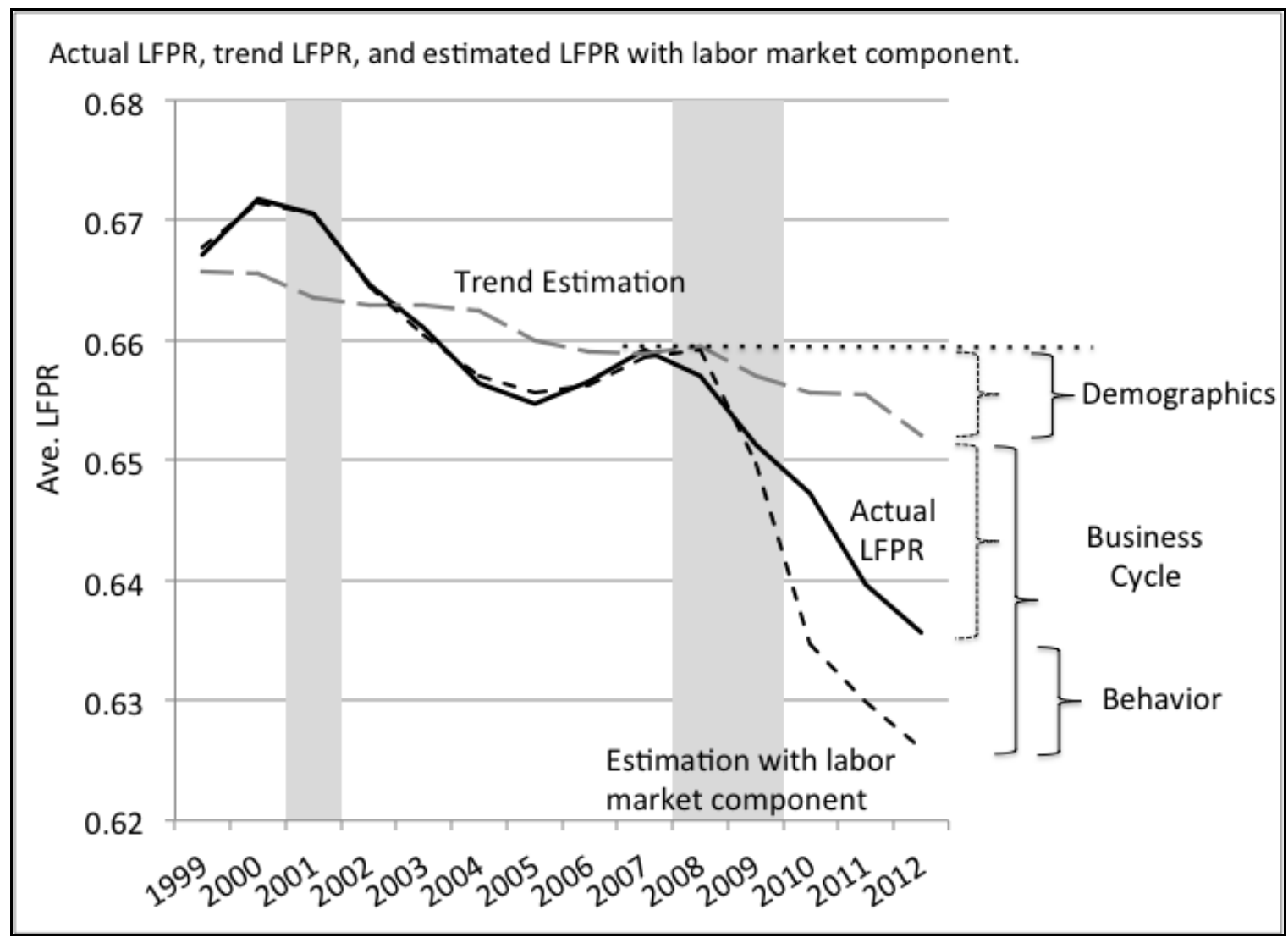

Figure 2. Actual and predicted labor force participation rates with and without labor market attachment. ${ }^{\mathrm{vi}}$

The gray dashed line in Figure 2 reflects the estimation of trend LFPR, estimated in the spirit of Aaronson et al. (2012, graph 3) and Van Zandweghe (2012, chart 13). This model is estimated using data between 1999 and 2007 then projects the LFPR out to 2012. ${ }^{\text {vii }}$ The black dashed line estimates the same model with the inclusion of a measure of the current labor market conditions (allowing for a direct role of the business cycle in labor force participation decisions). The dashed brackets reflect the typical decomposition found in the literature of the difference between the LFPR before the recession and after the recession into the portion of the difference accounted for by changes in demographics and by changes in the business cycle. Estimation with the inclusion of a behavioral response to the business cycle adds an additional dimension to the decomposition as illustrated by the solid brackets. As was seen in the decomposition above, allowing for direct influence of labor market conditions results in a much greater contribution being attributed to cyclical factors. The actual LFPR was higher in 2012 than the model would have predicted, given the severity of the labor market deterioration. 


\section{MInstitute Macrothink $_{\text {Int }}$}

Business and Economic Research ISSN 2162-4860 2013, Vol. 3, No. 1

Table 2 and Figure 2 both illustrate that while demographic changes (such as the changing age distribution) contributed to the decline in the LFPR, the deteriorating labor market was the primary contributor and that if behavior had not changed to bolster labor force participation, then 2012 would have seen an even lower LFPR than what appeared.

\subsection{Looking Forward}

Understanding the past can be useful in and of itself, but for purposes of policy-making, being able to use past information to look forward is often the ultimate goal. For example, what do the results of this analysis tell us to expect regarding potential labor supply several years out? If we expect the labor force participation rate to continue its decline, especially as the economy improves, this has negative implications for output potential.

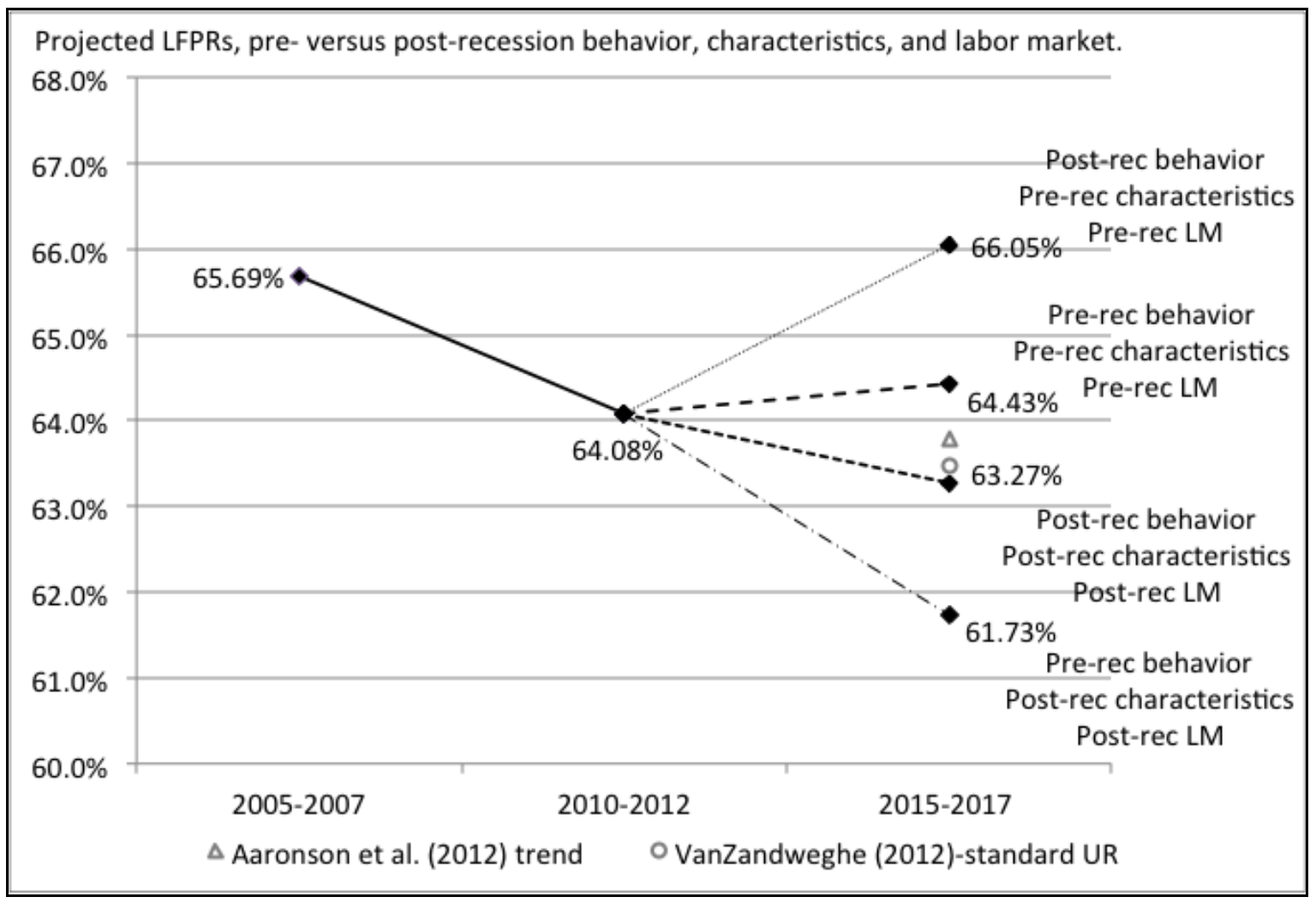

Figure 3. Projected LFPRs, pre- versus post-recession behavior, characteristics, and labor market. ${ }^{\text {viii }}$

Figure 3 presents estimates of the average labor force participation rate between 2015 and 2017 under four different scenarios. The scenarios reflect four different assumptions about labor market conditions, socio-demographic characteristics, and behavior. There are certain characteristics that we expect are not affected by movements in the business cycle -- these include age, race/ethnicity, and sex. For purposes of all four simulations in Figure 3, these characteristics are expected to progress on the same trend observed from 2005-2007 to 2010-2012.

As discussed above, there are certain socio-demographic characteristics that may very well be affected by the business cycle -- these include education, fertility, marriage, and other income. 
Assuming pre-recession characteristics means that we would expect fertility and marriage rates, and other income to return to pre-recession values. Education, however, will be kept at post-recession levels since there is no "undoing" this characteristic change of the sample. In other words, while improved economic conditions might induce an increase in fertility (or marriage), it won't induce someone to become less educated. However, we do not assume that the growth in educational attainment will continue into 2015-2017.

In discussion of the decomposition it was also noted that behavior changed in such a way as to put upward pressure on the LFPR (seen through the positive contribution of the coefficient effect in Table 2). Assumption of pre-recession behavior will apply the pre-recession parameter estimates and an assumption of post-recession behavior will apply the post-recession parameter estimates. Similarly, pre-recession and post-recession labor market will reflect the average number of weeks worked in the previous year observed before and after the recession, respectively.

We consider the most likely scenarios to be those that combine (rather than mix) pre- and post-recession behavior, characteristics, and labor market conditions. Our results suggest that between the years 2010-2012 and 2015-2017, the labor force participation rate will most likely either fall by $0.81 \mathrm{pp}$ if labor market conditions do not improve, or rise by $0.35 \mathrm{pp}$ if the labor market returns to pre-recession conditions. ${ }^{\text {ix }}$ This higher projected LFPR is still lower than the average LFPR pre-recession, reflecting the continued downward pressures of, primarily, an aging baby boom.

Using his base model, Van Zandweghe (2012) projects a decline in the LFPR of 0.6pp between 2011 and 2015. ${ }^{\mathrm{x}}$ However Van Zanweghe notes that if long-term unemployment was depressing post-recession labor force participation, LFPR may rise rather than fall over this time period.

\section{Implications}

The weakness of the labor market has been identified as a major contributor to the observed decline in the labor force participation rate during and after the recession of 2008-2009. Estimated contributions range from 50 to 75 percent of the decline. The analysis in this paper, by allowing the labor market conditions to have a direct influence on labor force participation behavior, finds that labor market conditions more than explain the decline in labor force participation rates from before to after the Great Recession. If individual behavior had not changed to boost participation, the observed LFPR would have been much lower than it actually was. The implication of these results is that if the labor market does not improve and behavior does not change, the LFPR will continue to fall by an additional $0.81 \mathrm{pp}$ by 2017 . If the labor market returns to pre-recession conditions and individual behavior follows suit, the labor force participation rate could rise by $0.35 \mathrm{pp}$-- still lower than pre-recession labor force participation, since we still face downward demographic trends, such as an aging baby boom.

Labor markets around the world also suffered from shocks attributed to the Great Recession. This analysis makes use of a standard set of responses to a typical household survey in the United States. These micro-level household data are readily available from other developed 
and developing countries (with varying degrees of repetition over time). Besides availability from the source country, researchers can access micro-level census data from two useful sources: The International Household Survey Network (http://www.surveynetwork.org) and IPUMS International (https://international.ipums.org/international/). ${ }^{\mathrm{xi}}$ Using these data, the methodology and analysis contained in this paper can be easily replicated for analyses relevant to other countries.

\section{Acknowledgement}

Views expressed here are not necessarily those of the Federal Reserve Bank of Atlanta or those of the Federal Reserve System. Comments and suggestions from Patrick Higgins, Dan Aaronson, Luoija $\mathrm{Hu}$, Christopher Bollinger, Tom Mroz, Willem Van Zandweghe and colleagues at the FRBA are much appreciated.

\section{References}

Aaronson, D., Davis, J., \& Hu, L. (2012, March). Explaining the Decline in the U.S. Labor Force Participation Rate. Chicago Fed Letter No. 296.http://www.chicagofed.org/webpages/publications/chicago_fed_letter/2012/march_296.c $\mathrm{fm}$

Barsky, R., Bound, J., Charles, K. K., \& Lupton, J. P. (2002). Accounting for The Black-White Wealth Gap: A Nonparametric Approach. Journal of the American Statistical Association, 97, 459, 663-73.http://www.jstor.org/stable/3085702

Blinder, A. S. (1973).Wage Discrimination: Reduced Form and Structural Estimates. Journal of Human Resource, 8(4), 436-455. http://www.jstor.org/stable/144855

DiNardo, J., Fortin, N. M., \& Lemieux, T. (1996). Labor Market Institutions and the Distribution of Wages, 1973-1992: a Semiparametric Approach. Econometrica, 64, 1001-44. http://www.jstor.org/stable/2171954

Elsby, M. W. L., Hobjin, B., \& Sahin, A. (2013). On the Importance of the Participation Margin for Labor Market Fluctuations. Federal Reserve Bank of San Francisco Working Paper \#2013-05.http://www.frbsf.org/publications/economics/papers/2013/wp2013-05.pdf

Firpo, S., Fortin, N., \& Lemieux, T. (2007, June). Decomposing Wage Distributions Using Recentered Influence Function Regressions. Mimeo, University of British Columbia.

Fortin, N., Lemieux, T., \& Firpo, S. (2010). Decomposition Methods in Economics. In O. Ashenfelter,\& D. Card (Eds.), Handbook of Labor Economics Vol. 4, Part A (pp. 1-102). Amsterdan:North-Holland.http://www.sciencedirect.com/science/article/pii/S0169721811004 072

Hirano, K., Imbens, G. W., \& Ridder, G. (2003). Efficient Estimation of Average Treatment Effects Using the Estimated Propensity Score. Econometrica, 7(4), 1161-89.http://www.jstor.org/stable/1555493

Hotchkiss, J. L. (2005, Q3). Changes in Behavioral and Characteristic Determination of 


\section{MInstitute Macrothink $_{\text {Int }}$}

Business and Economic Research ISSN 2162-4860

Female Labor Force Participation, 1975-2005.Federal Reserve Bank of Atlanta Economic Review.1-13. http://www.frbatlanta.org/filelegacydocs/erq206_hotchkiss.pdf

Hotchkiss, J. L., Pitts, M. M., \& Rios-Avila, F. (2012, August). A Closer Look at Nonparticipants During and After the Great Recession. Federal Reserve Bank of Atlanta Working Paper \# 2012-10.http://www.frbatlanta.org/pubs/wp/12_10.cfm

Imbens, G. W., \& Wooldridge, J. (2009). Recent Developments in the Econometrics of Program Evaluation. Journal of Economic Literature, 47(1), 5-86. http://www.aeaweb.org/articles.php?doi=10.1257/jel.47.1.5

Juhn, C., \& Potter, S. (2007, December). Is There Still an Added-Worker Effect? Staff Reports \#310, Federal Reserve Bank of New http://www.newyorkfed.org/research/staff_reports/sr310.html

Kudlyak, M., \& Schwartzman, F. (2012, June 5). Accounting for Unemployment in the Great Recession: Nonparticipation Matters. Federal Reserve Bank of Richmond Working Paper \#12-04. http://richmondfed.org/publications/research/working_papers/2012/pdf/wp12-04.pdf

Maki, D., Davig, T., \& Newland, P. (2012, March 1). Dispelling an Urban Legend: US Labor Force Participation Will Not Stop the Unemployment Rate Decline. Barclays Capital.

Morgan, S. P., Cumber worth, E., \& Wimer, C. (2012). Family, the Life course and the Great Recession. Recession Trends. Russell Sage Foundation, http://www.russellsage.org/research/reports/family-great-recession

Oaxaca, R. L. (1973). Male-Female Wage Differentials in Urban Labor Markets. International Economic Review, 14(3), 693-709.http://www.jstor.org/stable/10.2307/2525981

Rosenbaum, P. R., \& Rubin, D. B. (1985). Constructing a Control Group Using Multivariate Matched Sampling Methods that Incorporate the Propensity Score. The American Statistician, 39(1), 33-8.http://www.jstor.org/stable/2683903

Stehn, S. J. (2012, February 6). US Daily: Labor Force Participation: Cyclical Boost, Structural Drag.Goldman Sachs.

Van Zandweghe, W. (2012, Q1). Interpreting the Recent Decline in Labor Force Participation. Federal Reserve Bank of Kansas City Economic Review, 5-34. http://www.kc.frb.org/publicat/econrev/pdf/12q1VanZandweghe.pdf

\section{Appendix 1: Linear Probability Estimates from Re-weighting Strategy}

The parameter estimates corresponding to equations (3) - (5) in the text are contained here in Table 1.1.All regressors influence labor force participation as expected. Participation increases with age until 55 years; men, those without children, married individuals, the more educated, and those with less non-labor income, ceteris paribus, are more likely to participate in the labor market. And, lastly, stronger labor markets induce greater labor force participation. 
Women, individuals with young children, and those who are married with their spouse present are all more likely (holding everything else constant) to be participating post-recession than they were pre-recession. Increased participation among these individuals likely reflects the added worker effect (e.g., see Juhn and Potter 2007). There was no significant difference across the two time periods in how the condition of the labor market affected labor force participation decisions.

Table 1.1. Linear probability estimation of labor force participation using pre-recession, post-recession, and reweighted post-recession samples.

\begin{tabular}{|c|c|c|c|}
\hline Sample $=$ & $\begin{array}{c}\text { Pre } \\
\text { Recession }\end{array}$ & $\begin{array}{c}\text { Post } \\
\text { Recession }\end{array}$ & $\begin{array}{c}\text { Post } \\
\text { Reweighted }\end{array}$ \\
\hline \multicolumn{4}{|l|}{ Age } \\
\hline Age group 16-19 & $\begin{array}{l}0.456^{*} \\
(0.004) \\
\end{array}$ & $\begin{array}{l}0.379^{*} \\
(0.004)\end{array}$ & $\begin{array}{l}0.367 * \\
(0.004) \\
\end{array}$ \\
\hline Age group 20-34 & $\begin{array}{l}0.703 * \\
(0.002)\end{array}$ & $\begin{array}{l}0.684 * \\
(0.002)\end{array}$ & $\begin{array}{l}0.690^{*} \\
(0.003)\end{array}$ \\
\hline Age group 35-54 & $\begin{array}{l}0.714^{*} \\
(0.002) \\
\end{array}$ & $\begin{array}{l}0.705^{*} \\
(0.002) \\
\end{array}$ & $\begin{array}{l}0.714 * \\
(0.003) \\
\end{array}$ \\
\hline Age group 55-74 & $\begin{array}{l}0.382 * \\
(0.003) \\
\end{array}$ & $\begin{array}{l}0.397 * \\
(0.003) \\
\end{array}$ & $\begin{array}{l}0.417^{*} \\
(0.003) \\
\end{array}$ \\
\hline \multicolumn{4}{|l|}{ Sex and Ethnicity } \\
\hline Female $(=1)$ & $\begin{array}{l}-0.109^{*} \\
(0.001)\end{array}$ & $\begin{array}{l}-0.099 * \\
(0.001)\end{array}$ & $\begin{array}{l}-0.098^{*} \\
(0.001)\end{array}$ \\
\hline Hispanic or Black & $\begin{array}{l}-0.031 * \\
(0.002)\end{array}$ & $\begin{array}{l}-0.031 * \\
(0.002)\end{array}$ & $\begin{array}{l}-0.020^{*} \\
(0.002)\end{array}$ \\
\hline \multicolumn{4}{|l|}{ Household Characteristics } \\
\hline \# children younger than 6 & $\begin{array}{l}-0.038^{*} \\
(0.001) \\
\end{array}$ & $\begin{array}{l}-0.029^{*} \\
(0.001) \\
\end{array}$ & $\begin{array}{l}-0.028^{*} \\
(0.001) \\
\end{array}$ \\
\hline$\#$ children aged $6-18$ & $\begin{array}{l}0.001^{\wedge} \\
(0.001) \\
\end{array}$ & $\begin{array}{c}-0.001 \\
(0.001) \\
\end{array}$ & $\begin{array}{c}-0.003^{*} \\
(0.001) \\
\end{array}$ \\
\hline Married, Spouse present & $\begin{array}{l}0.031^{*} \\
(0.002)\end{array}$ & $\begin{array}{l}0.036^{*} \\
(0.002) \\
\end{array}$ & $\begin{array}{l}0.034^{*} \\
(0.002)\end{array}$ \\
\hline \multicolumn{4}{|l|}{ Education } \\
\hline High School & $\begin{array}{l}0.147 * \\
(0.002) \\
\end{array}$ & $\begin{array}{l}0.155^{*} \\
(0.002) \\
\end{array}$ & $\begin{array}{l}0.137^{*} \\
(0.002) \\
\end{array}$ \\
\hline Some College & $\begin{array}{l}0.152^{*} \\
(0.003) \\
\end{array}$ & $\begin{array}{l}0.151^{*} \\
(0.003) \\
\end{array}$ & $\begin{array}{l}0.140^{*} \\
(0.003) \\
\end{array}$ \\
\hline BA degree & $\begin{array}{l}0.222^{*} \\
(0.003) \\
\end{array}$ & $\begin{array}{l}0.242^{*} \\
(0.003) \\
\end{array}$ & $\begin{array}{l}0.201 * \\
(0.003) \\
\end{array}$ \\
\hline Graduate Degree & $\begin{array}{l}0.275^{*} \\
(0.003)\end{array}$ & $\begin{array}{l}0.289^{*} \\
(0.003)\end{array}$ & $\begin{array}{l}0.243^{*} \\
(0.003)\end{array}$ \\
\hline \multicolumn{4}{|l|}{ Other Income } \\
\hline Non Labor income & $\begin{array}{l}-0.001 * \\
(0.000)\end{array}$ & $\begin{array}{l}-0.001 * \\
(0.000)\end{array}$ & $\begin{array}{l}-0.001 * \\
(0.000)\end{array}$ \\
\hline
\end{tabular}




\begin{tabular}{|c|c|c|c|}
\hline Disability Income & $\begin{array}{c}-0.000 * \\
(0.000) \\
\end{array}$ & $\begin{array}{c}-0.000 * \\
(0.000) \\
\end{array}$ & $\begin{array}{c}-0.000 * \\
(0.000)\end{array}$ \\
\hline Labor Market Conditions & $\begin{array}{c}0.014 * \\
(0.000)\end{array}$ & $\begin{array}{c}0.014 * \\
(0.000)\end{array}$ & $\begin{array}{l}0.014 * \\
(0.000)\end{array}$ \\
\hline Constant & $\begin{array}{c}-0.403 * \\
(0.013) \\
\end{array}$ & $\begin{array}{c}-0.403 * \\
(0.011) \\
\end{array}$ & $\begin{array}{c}-0.401 * \\
(0.012) \\
\end{array}$ \\
\hline $\mathrm{N}$ & 457465 & 459027 & 459027 \\
\hline R2-adjust & 0.282 & 0.271 & 0.278 \\
\hline
\end{tabular}

Notes: Robust standard errors in parentheses. Pre-recession includes observations from 2005-2007, post-recession includes observations from 2010-2012. Excluded categories include those aged 75+, less than high school education, male, not married, and whites. Urban CPI is used to deflate dollar values of other income. Labor market conditions are measured by the average number of weeks worked in the previous year in by year and state of residence.

$+\mathrm{p}<0.05, * \mathrm{p}<0.01$.

\section{Appendix 2: Oaxaca-Blinder Decomposition Results}

This appendix reports the decomposition results from implementation of the standard Oaxaca-Blinder methodology. Using the parameter coefficients from estimating equations (3) and (4) in the text (reported in Table 1), the observed difference in the average pre- and post-recession LFPRs is then decomposed into its different components:

$$
\begin{aligned}
\overline{L F P_{1}}-\overline{L F P_{0}}= & \left(\hat{\alpha}_{1}-\hat{\alpha}_{0}\right)+\bar{X}_{0}{ }^{\prime}\left(\hat{\beta}_{1}-\hat{\beta}_{0}\right)+\left(\bar{X}_{1}-\bar{X}_{0}\right)^{\prime} \hat{\beta}_{1} \\
& +L M_{0}{ }^{\prime}\left(\hat{\gamma}_{1}-\hat{\gamma}_{0}\right)+\left(L M_{1}-L M_{0}\right)^{\prime} \hat{\gamma}_{1},
\end{aligned}
$$

where $\left(\hat{\alpha}_{1}-\hat{\alpha}_{0}\right)$ captures the change in average LFP that can not be explained by all of the other components; $\left[\bar{X}_{0}^{\prime}\left(\hat{\beta}_{1}-\hat{\beta}_{0}\right)\right]$ and $\left[\left(\bar{X}_{1}-\bar{X}_{0}\right)^{\prime} \hat{\beta}_{1}\right]$ will reflect the contribution of changes in behavior (coefficients) and changes in characteristics (endowments), respectively, to the difference in LFP; and $L M_{0}{ }^{\prime}\left(\hat{\gamma}_{1}-\hat{\gamma}_{0}\right)$ and $\left(L M_{1}-L M_{0}\right)^{\prime} \hat{\gamma}_{1}$ will reflect the contributions of changes in how individuals adjust labor force participation decisions in consideration of labor market conditions and changes in labor market conditions, respectively. Table 2.1 contains the results from the decomposition. Parameter estimates are the same as those reported in Appendix 1, Table 1.1, for the pre- and post-recession samples.

Overall, the largest contributing factor to the decline in the LFPR was changes in characteristics, with most of that contribution being explained by the decline in the labor market. As pointed out in the paper, the contribution attributed to the labor market in Table 2.1 is smaller (closer to zero) than estimated using the re-weighting strategy. This makes sense if 
some of the labor market effect is being absorbed by changes in characteristics, such as increased educational attainment and reduced fertility. Both of these characteristic changes would increase labor force participation, and when removed from the post-recession distribution has the effect of leaving more to be explained by the declining labor market.

Table 2.1. Detailed decomposition of decline in labor force participation using the Oaxaca-Blinder decomposition methodology.

\begin{tabular}{|c|c|c|}
\hline$\overline{L F P}_{1}-\overline{L F P}_{0}=0.641-0.657=-0.016$ & $\begin{array}{c}\text { Contribution of } \\
\text { changes in } \\
\text { Endowments }\end{array}$ & $\begin{array}{c}\text { Contribution of } \\
\text { changes in } \\
\text { Coefficients }\end{array}$ \\
\hline Total & $-0.0302 *$ & $0.0142 *$ \\
\hline Age: & $-0.0080 *$ & $-0.0109 *$ \\
\hline Age group 16-19 & $\begin{array}{l}-0.0008 * \\
{[0.0002]}\end{array}$ & $\begin{array}{l}-0.0056 * \\
{[0.0004]}\end{array}$ \\
\hline Age group 20-34 & $\begin{array}{l}-0.0008 \\
{[0.0008]}\end{array}$ & $\begin{array}{l}-0.0050 * \\
{[0.0009]}\end{array}$ \\
\hline Age group 35-54 & $\begin{array}{l}-0.0175^{*} \\
{[0.0008]}\end{array}$ & $\begin{array}{l}-0.0034 * \\
{[0.0012]}\end{array}$ \\
\hline Age group 55-74 & $\begin{array}{l}0.0110^{*} \\
{[0.0004]}\end{array}$ & $\begin{array}{l}0.0033^{*} \\
{[0.0008]}\end{array}$ \\
\hline Sex and Ethnicity & -0.0001 & $0.005 *$ \\
\hline Female $(=1)$ & $\begin{array}{c}0.0001 \\
{[0.0001]}\end{array}$ & $\begin{array}{l}0.0050 * \\
{[0.0011]}\end{array}$ \\
\hline Hispanic or Black & $\begin{array}{l}-0.0002 * \\
{[0.0000]}\end{array}$ & $\begin{array}{c}0.0000 \\
{[0.0004]}\end{array}$ \\
\hline Household Characteristics & $-0.0002 *$ & $0.0029+$ \\
\hline \# children younger than 6 & $\begin{array}{l}0.0005^{*} \\
{[0.0000]}\end{array}$ & $\begin{array}{l}0.0017 * \\
{[0.0004]}\end{array}$ \\
\hline \# children aged $6-18$ & $\begin{array}{c}0.0000 \\
{[0.0000]}\end{array}$ & $\begin{array}{l}-0.0012+ \\
{[0.0006]}\end{array}$ \\
\hline Married, Spouse present & $\begin{array}{l}-0.0007^{*} \\
{[0.0001]}\end{array}$ & $\begin{array}{l}0.0026+ \\
{[0.0013]}\end{array}$ \\
\hline Education & $0.0057 *$ & $0.0072 *$ \\
\hline High School & $\begin{array}{l}-0.0005^{*} \\
{[0.0002]}\end{array}$ & $\begin{array}{l}0.0029+ \\
{[0.0013]}\end{array}$ \\
\hline Some College & $\begin{array}{l}0.0005^{*} \\
{[0.0001]}\end{array}$ & $\begin{array}{c}-0.0002 \\
{[0.0007]}\end{array}$ \\
\hline BA degree & $\begin{array}{c}0.0027^{*} \\
{[0.0002]}\end{array}$ & $\begin{array}{c}0.0032 * \\
{[0.0006]}\end{array}$ \\
\hline Graduate Degree & $\begin{array}{c}0.0029 * \\
{[0.0002]}\end{array}$ & $\begin{array}{c}0.0011 * \\
{[0.0004]}\end{array}$ \\
\hline
\end{tabular}




\begin{tabular}{|c|c|c|}
\hline & & \\
\hline Other Income & $\mathbf{0 . 0 0 1 2} *$ & $\mathbf{0 . 0 0 0 2}$ \\
\hline Non Labor income & $0.0008^{*}$ & 0.0004 \\
{$[0.0001]$} & {$[0.0009]$} \\
\hline Disability Income & $0.0004^{*}$ & $-0.0003+$ \\
& {$[0.0001]$} & {$[0.0001]$} \\
\hline & & $\mathbf{0 . 0 0 9 4}$ \\
& {$[0.0177]$} \\
\hline Labor Market Conditions & {$[0.0008]$} & \\
\hline Constant & & 0.0003 \\
& & {$[0.0175]$} \\
\hline
\end{tabular}

Notes: Robust standard errors in parentheses. Pre-recession includes observations from 2005-2007, post-recession includes observations from 2010-2012. Excluded categories include those aged 75+, less than high school education, male, not married, and whites. Urban CPI is used to deflate dollar values of other income. Labor market conditions are measured by the average number of weeks worked in the previous year in by year and state of residence.

$+\mathrm{p}<0.05, * \mathrm{p}<0.01$

\section{Endnotes}

${ }^{i}$ Source of data for Figure 1 is the Current Population Survey, Household Survey. See www.bls.gov/bls/glossery.html\#L for the U.S. Bureau of Labor Statistics definition of the labor force and the labor force participation rate.

ii These weights are the inverse of the estimated propensity score. Estimated propensity scores are used in matching procedures employed to obtain a control group in non-experimental settings (e.g., see Rosenbaum and Rubin 1985).

iii Ignorability requires that after controlling for observed characteristics, the distribution of the unobserved explanatory factors in the LFP equation are the same across before and after the recession. Whereas overlapping requires that there should be enough observations to identify the controls for all observations in the sample.

iv We estimate the models as a maximum likelihood probit model with no appreciable difference in results. CPS final weights are used in all estimations and calculations of means.

v Van Zanweghe (2012) estimates that if long-term unemployment is depressing labor force participation, then cyclical factors have likely contributed to 90 percent of the observed decline in the LFPR.

vi Notes to Figure 2: Gray bars reflect recessionary periods. Trend estimation refers to estimation of LFP as a linear probability function of age categorical dummies; female and race dummies; household characteristics (children, married); education categorical groups; 
family non-labor income including disability; age and education interactions; cohort fixed effects (five cohorts are defined: 1914-1926, 1927-1945, 1946-1964, 1965-1982 and 1983-1996.), and state fixed effects. Estimation with labor market component also includes the average number of weeks worked in the previous year by state of residence. Data for the observed CPS-LFP is Bureau of Labor Statistics, Current Population Survey.

vii Using the GDP gap as a measure of the business cycle, Aaronson et al. (2012) produces a trend LFPR that ends up 1.1pp above their actual LFPR in 2011. Van Zanweghe (2012) uses the standard aggregated unemployment rate and produces a trend LFPR that is approximately $0.8 \mathrm{pp}$ above the actual LFPR in 2011. Our estimated trend line is 1.6pp above the actual LFPR.

viii Notes to Figure 3: Socio-demographic characteristics not expected to be influenced by economic conditions (age, sex, and race/ethnicity) are projected to change by the same amount and in the same direction as they changed from pre- to post-recession. Characteristics expected to be influenced by economic conditions (fertility, marriage, and other income) will be set at pre-recession values for the simulation assuming return to pre-recession characteristics. Education is assumed to remain at its 2010-2012 levels -- not reverting to pre-recession levels and not continuing its growth from 2005-2007 to 2010-2012. Pre- and post-recession behavior and pre- and post-recession labor market reflect which parameter estimates and measure of labor market conditions that are used for the simulation. Aaronson et al. (2012) trend projection is calculated as $64.08 \%$ plus $1.1 \mathrm{pp}$ (the amount by which Aaronson et al. calculates we are below trend) minus 1.4pp (the amount Aaronson et al. calculate the trend will fall between 2011 and 2016); note Aaronson et al. performs all of their analyses on a sample aged 16-79. Van Zandweghe (2012) projects an increase in LFPR by 2015 if participation is depressed because of long-term unemployment.

ix Improvement of labor market conditions is simulated as a return to the values of weeks worked in the previous year observed in 2005-2007, however, weighted by the age and education distributions expected to exist in 2015-2017.

x Aaronson et al. (2012) project a trend decline (i.e., absent any cyclical influences) of 1.4pp between 2011 and 2016. Van Zanveghe (2012) also projects a 1.4pp decline in the trend LFPR (between 2011 and 2015).

xi A list of countries and years for which census data are available can be found directly at http://www.surveynetwork.org.

\section{Copyright Disclaimer}

Copyright reserved by the author(s).

This article is an open-access article distributed under the terms and conditions of the Creative Commons Attribution license (http://creativecommons.org/licenses/by/3.0/). 